\title{
Soil Characteristic Comparison of Fenced and Grazed Riparian Floodplain Wetlands in the Typical Steppe Region of the Inner Mongolian Plateau, China
}

\author{
Lixin Wang, ${ }^{1}$ Huamin Liu, ${ }^{2}$ Yuhong Liu, ${ }^{1,3}$ Jianwei Li, ${ }^{1,4}$ Hongbo Shao, ${ }^{3}$ \\ Wei Wang, ${ }^{2}$ and Cunzhu Liang ${ }^{2}$ \\ ${ }^{1}$ College of Environment and Resources, Inner Mongolia University, Hohhot 010021, China \\ ${ }^{2}$ College of Life Sciences, Inner Mongolia University, Hohhot 010021, China \\ ${ }^{3}$ Yantai Institute of Coastal Zone Research, Chinese Academy of Sciences, Yantai 264003, China \\ ${ }^{4}$ BERIS Engineering and Research Corporation, Baotou 014010, China \\ Correspondence should be addressed to Yuhong Liu; yhliu@yic.ac.cn and Hongbo Shao; shaohongbochu@126.com
}

Received 19 March 2014; Accepted 24 March 2014; Published 19 May 2014

Academic Editor: Xu Gang

Copyright ( 2014 Lixin Wang et al. This is an open access article distributed under the Creative Commons Attribution License, which permits unrestricted use, distribution, and reproduction in any medium, provided the original work is properly cited.

\begin{abstract}
In recent decades, degradation of ecosystem in the steppe region of the Inner Mongolia Plateau, especially in riparian floodplain wetlands, has become a significant ecological crisis. Not uncommonly, with the increasing of livestock in the Inner Mongolian steppe region, a riparian floodplain wetland is becoming a hotspot area of grazing for local herdsmen. Hence, it is essential to understand degradation mechanisms of riparian floodplain wetland ecosystems caused by extensive grazing. In this study, the spatial distribution of soil compaction, salinity, total nitrogen, total phosphorus, organic carbon, and microbial biomass $\mathrm{C}$ and $\mathrm{N}$ were investigated. The results showed that grazing led to an increase in soil compaction and soil surface salinity, which significantly lowered levels of total N, P, and TOC in the soil surface. Grazing decreased soil microbial biomass C and N concentration in the lower riparian floodplain wetland, whereas it significantly increased soil microbial biomass $\mathrm{C}$ and $\mathrm{N}$ concentration in the higher riparian floodplain wetland. Elevation differences in the riparian floodplain wetland increased spatial heterogeneity in the soil and thus resulted in different influence of grazing on wetland soils and ecosystem. Therefore, elevation differences and grazing intensity were the main factors controlling soil characteristics in the riparian floodplain wetland of this region.
\end{abstract}

\section{Introduction}

The restoration and degradation characteristics of degraded riparian wetlands have become an important subject in wetland ecological studies [1-4]. Presently, most studies focused on decreases in wetland area and species succession, underlying degradation mechanisms affected by climate change $[5,6]$, land use [5-8], and overgrazing [9-14], and changes in nutrient composition of degraded wetlands [15-18].

With the increasing of livestock in the Inner Mongolian steppe region, grazing intensity also increased, which led to grassland degradation at various degrees $[19,20]$ and greatly decreases productivity [21, 22], hence existing pastures for grazing were not big enough to supply enough food for the livestock, and local people were transferring their livestock from grasslands to adjacent riparian floodplain wetlands $[23,24]$. As a result, vegetation and soil physical and chemical properties of riparian floodplain wetland began to degrade, and riparian floodplain wetland ecosystem health was affected by grazing intensity. Although grazing effects on typical steppe ecosystems have been thoroughly studied, which includes biodiversity, grassland productivity, soil physical and chemical properties, and changes in the succession of degraded plant communities [24-31], few studies were carried on the influences of grazing on adjacent riparian wetland soil and their underlying mechanisms of degradation in this region.

In this study, a fenced conservation and a degraded grazing riparian floodplain wetland with similar initial 


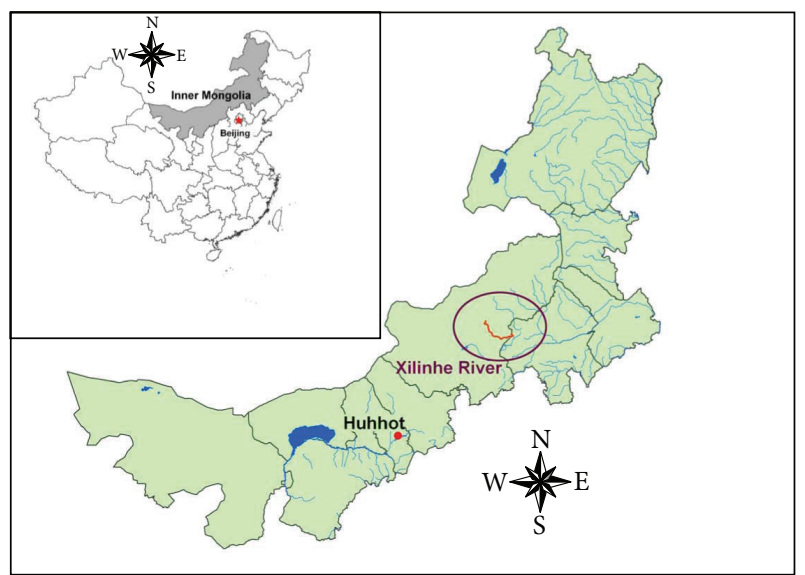

FIgURE 1: Location of Xilin River in Inner Mongolia, China.

environmental conditions were chosen as experiment sites in the riparian floodplain wetland of the Xilin River in the typical steppe region in the Inner Mongolian Plateau. Soil properties and its nutrient contents of grazed and fenced river floodplain wetlands were investigated, and these characteristics were compared in order to provide a theoretical foundation for sustainable development and managing of wetland natural resources in the steppe regions of the Inner Mongolian Plateau. We hypothesized that (1) direct grazing and trampling would increase soil compaction and decrease soil carbon content and (2) various elevations would affect levels of inundation in riparian floodplain wetland, and this would change distribution of grazing intensity, whereas vegetation compositions and soil properties in different locations of floodplain wetland also would be altered accordingly.

\section{Study Areas}

The Xilin River, one of the major inland rivers, flows from southeast to northwest, and its floodplain with a total area of $10,000 \mathrm{~km}^{2}$ is located at the eastern edge of the Xilingol High Plain in the middle of the Inner Mongolian Plateau (Figure 1). The elevation of the Xilin River watershed varies from 1,000 m to $1,500 \mathrm{~m}$ and decreases from east to west. The climate in the Xilin River watershed is described as a continental temperate steppe climate. The vegetation consists of typical steppe vegetation and the soil is mainly dark Kastanozems and light Kastanozems. The local economy is livestock-based.

Experiment sites, including grazed site and fenced site, were designed in the floodplain of the middle reach of the Xilin River $500 \mathrm{~m}$ away from the west of the Inner Mongolian Grassland Ecosystem Research Station of the Chinese Academy of Sciences with an elevation of 1,177 m $\left(43^{\circ} 37^{\prime} 40^{\prime \prime} \mathrm{N}, 116^{\circ} 41^{\prime} 11^{\prime \prime} \mathrm{E}\right)$. Overgrazing and trampling caused by nearby livestock existed on the degraded grazed site, whereas the fenced site was enclosed to exclude grazing livestock. The two sites were separated by a fence (at $35 \mathrm{~m}$ on the $x$-axis in Figure 2) and had similar initial environmental

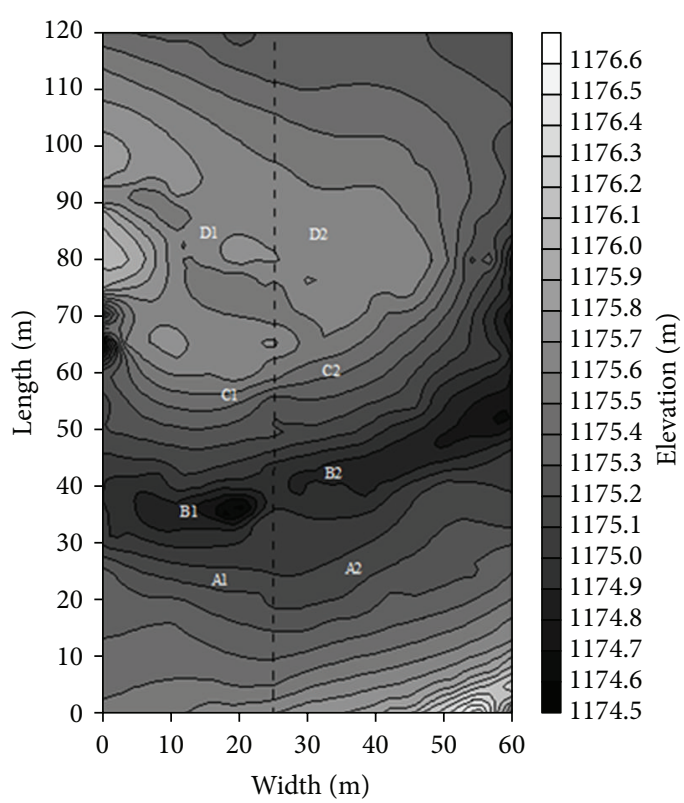

FIGURE 2: Topographical map of the study sites.

conditions. To eliminate the influence of microtopography on soil physical and chemical properties, wetland soil characteristics at locations $\mathrm{A}, \mathrm{B}, \mathrm{C}$, and D with similar topography were compared in the two sites (Figure 2). The species compositions of the fenced and grazed wetland were listed in Table 1.

\section{Methods}

3.1. Field Sampling and Laboratory Analysis. The samples of wetland soil were collected from $0-10 \mathrm{~cm}, 10-20 \mathrm{~cm}, 20-$ $30 \mathrm{~cm}, 30-40 \mathrm{~cm}$, and $40-50 \mathrm{~cm}$ by a soil auger with three replicates at each depth during the growing season in 2010. Soil compaction was measured by using the Soil Hardness Meter 6110 FS. Three soil samples obtained by cutting ring with a volume of $100 \mathrm{~cm}^{3}$ were taken to the laboratory and dried at $108^{\circ} \mathrm{C}$ until constant weight in order to measure soil bulk density. Soil samples from different depths, from which plant tissues were removed, were air-dried and the remaining soil materials were then sieved through a $2 \mathrm{~mm}$ filter. About one-fourth of each sample was ground using a globe grinder RetschRM100, passed through a number 100 sieve $(d=$ $150 \mu \mathrm{m})$, and then stored in glass vials for analyzing its chemical and physical properties. Soil total nitrogen $(\mathrm{N})$ content, soil total phosphorus $(\mathrm{P})$ content, and soil organic carbon (TOC) were measured by using a UDK $142+$ DK20 Kjeltec Auto Analyzer, the Molybdenum blue colorimetric method [32], and a Liqui TOC analyzer (Germany) [33], respectively. $\mathrm{C}$ and $\mathrm{N}$ contents of soil microbial biomass were determined by using the chloroform fumigation- $\mathrm{K}_{2} \mathrm{SO}_{4}$ extraction method [34]. Soil salinity was tested by using a Spectrum 2265 FS [35], and pH was determined using a Spectrum IQ150 [36]. 
TABLE 1: The composition of plant community in the study sites.

\begin{tabular}{|c|c|c|c|c|c|c|}
\hline \multirow{2}{*}{ Topography } & \multicolumn{3}{|c|}{ Fenced } & \multicolumn{3}{|c|}{ Grazed } \\
\hline & $\begin{array}{c}\text { Plant } \\
\text { community }\end{array}$ & $\begin{array}{l}\text { Plant height } \\
(\mathrm{cm})\end{array}$ & $\begin{array}{l}\text { Aboveground } \\
\text { biomass } \\
\left(\mathrm{g} / \mathrm{m}^{2}\right)\end{array}$ & $\begin{array}{l}\text { Plant } \\
\text { community }\end{array}$ & $\begin{array}{l}\text { Plant height } \\
(\mathrm{cm})\end{array}$ & $\begin{array}{c}\text { Aboveground } \\
\text { biomass } \\
\left(\mathrm{g} / \mathrm{m}^{2}\right)\end{array}$ \\
\hline \multirow[t]{2}{*}{$\begin{array}{l}\text { Low } \\
\text { floodplain } \\
\text { wetlands }\end{array}$} & $\begin{array}{l}\text { Glyceria spiculosa }+ \text { Poa } \\
\text { subfastigiata }(\mathrm{A} 1)\end{array}$ & $40.66 \pm 12.99$ & $415.31 \pm 128.84$ & $\begin{array}{c}\text { Carex appendiculata }+ \\
\text { Geranium vlassowianum } \\
\text { (A2) }\end{array}$ & $18.63 \pm 8.07$ & $329.44 \pm 40.17$ \\
\hline & $\begin{array}{l}\text { Carex. appendiculata }+ \\
\text { Eleocharis valleculosa (B1) }\end{array}$ & $47.57 \pm 17.07$ & $889.49 \pm 57.96$ & $\begin{array}{c}\text { Leymus chinensis + } \\
\text { Melilotus officinalis (B2) }\end{array}$ & $38.67 \pm 21.76$ & $483.09 \pm 181.44$ \\
\hline $\begin{array}{l}\text { Transition } \\
\text { zone }\end{array}$ & $\begin{array}{l}\text { Carex. appendiculata + } \\
\text { Glyceria spiculosa }(\mathrm{C} 1)\end{array}$ & $34.26 \pm 10.46$ & $467.92 \pm 144.35$ & $\begin{array}{c}\text { Glyceria spiculosa + } \\
\text { Agrostis gigantea (C2) }\end{array}$ & $14.03 \pm 7.49$ & $262.56 \pm 94.45$ \\
\hline $\begin{array}{l}\text { High floodplain } \\
\text { wetlands }\end{array}$ & $\begin{array}{c}\text { Leymus chinensis + Carex } \\
\text { korshinskii (D1) }\end{array}$ & $26.07 \pm 21.49$ & $251.41 \pm 126.04$ & $\begin{array}{c}\text { Leymus chinensis }+ \\
\text { Artemisia tanacetifolia (D2) }\end{array}$ & $15.43 \pm 9.72$ & $138.77 \pm 24.23$ \\
\hline
\end{tabular}

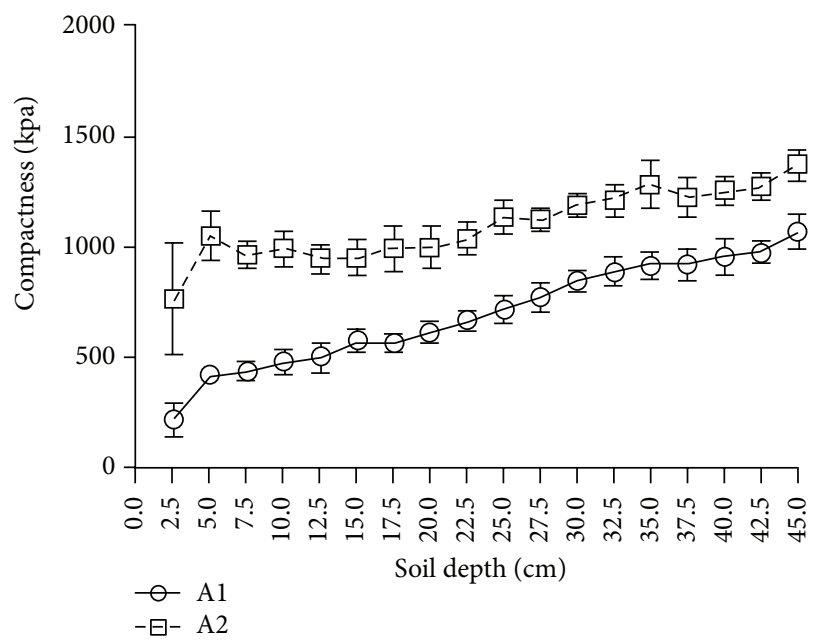

(a)

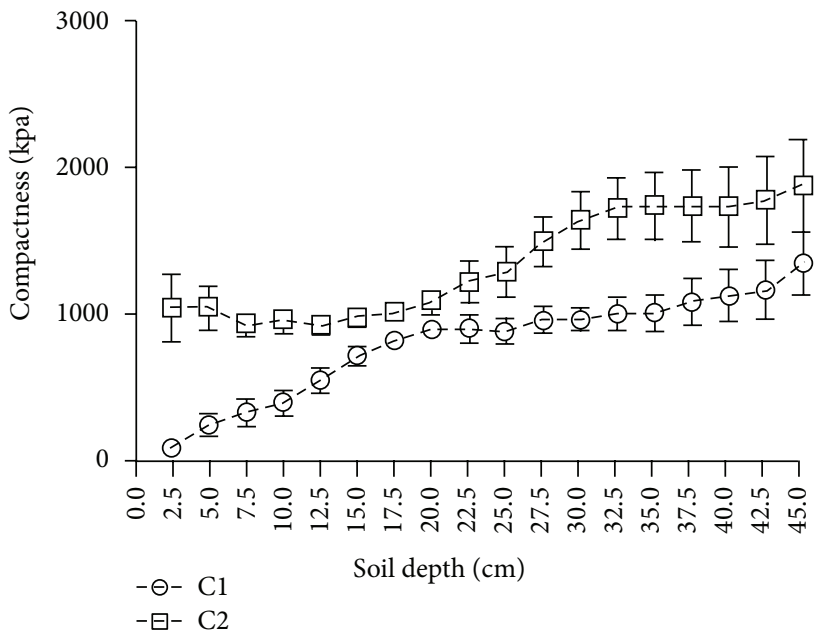

(c)

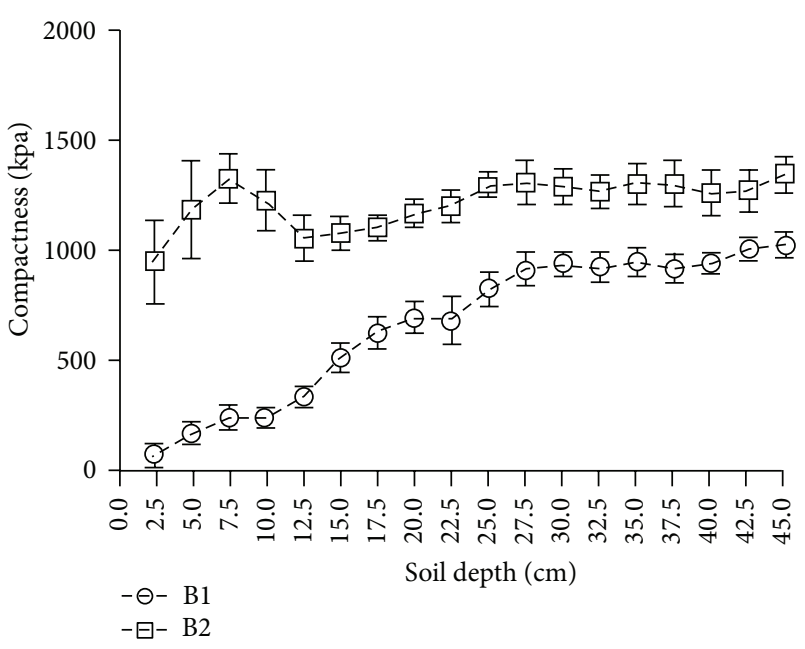

(b)

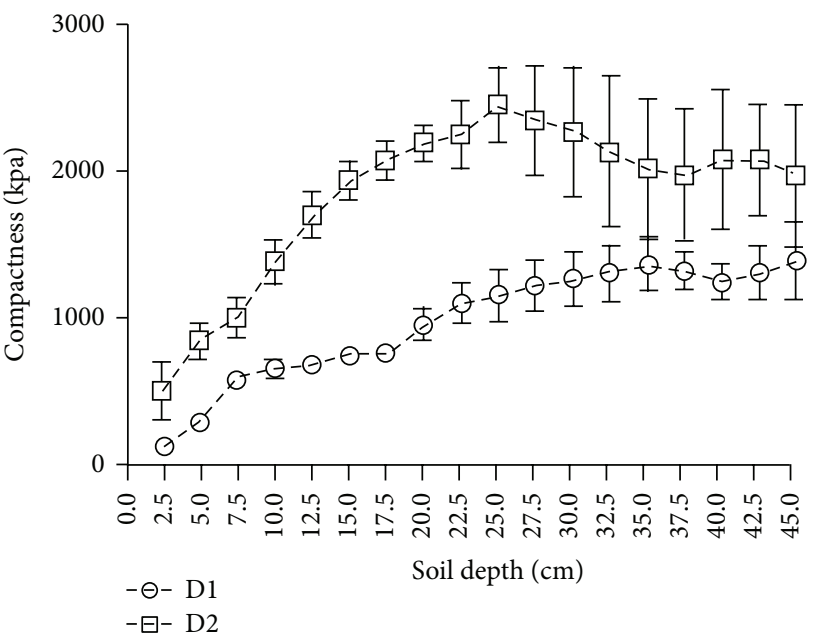

(d)

FIGURE 3: Spatial distribution of soil compaction. 


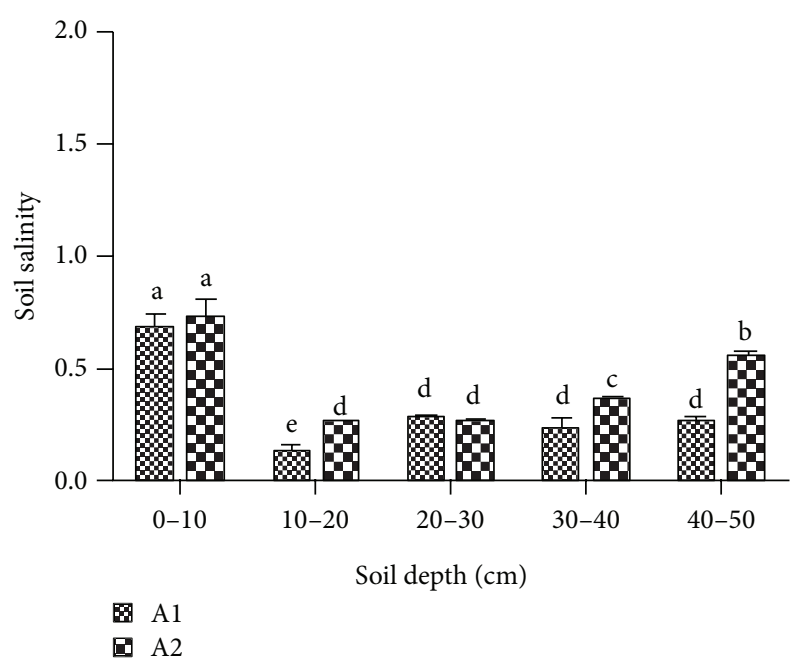

(a)

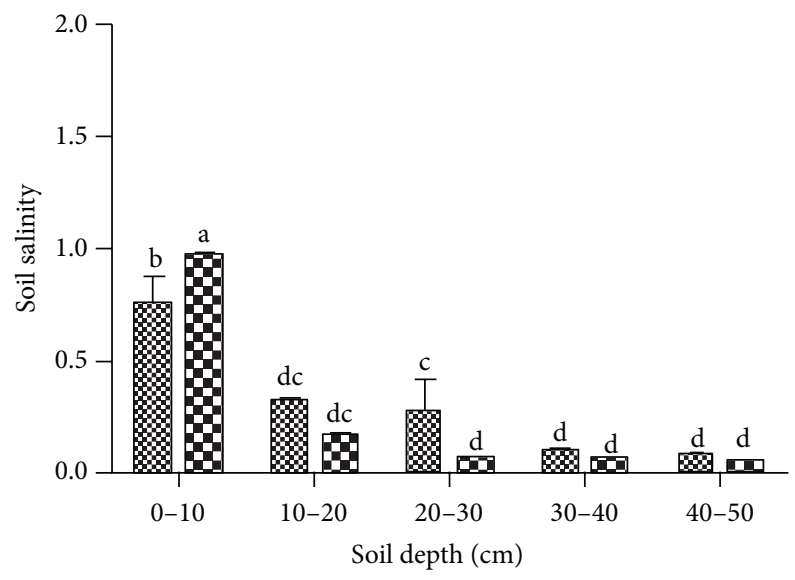

B $\mathrm{C} 1$

田2

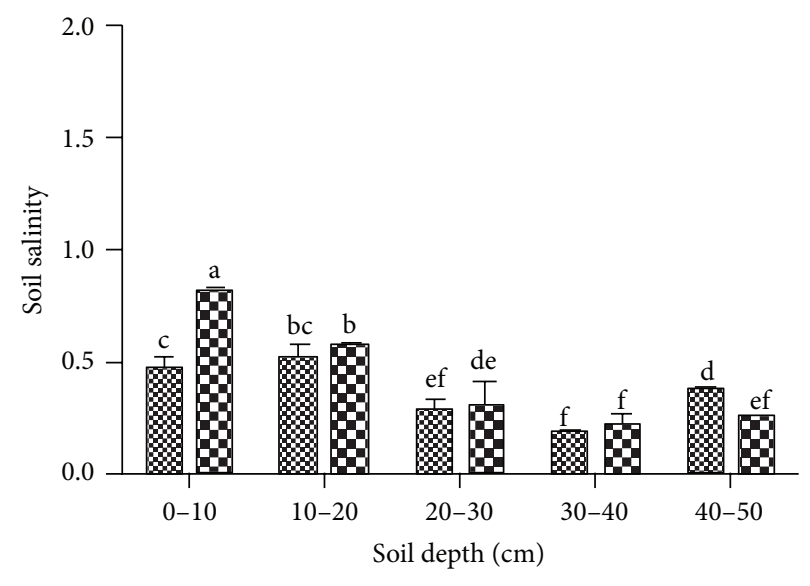

요 1

B2

(b)

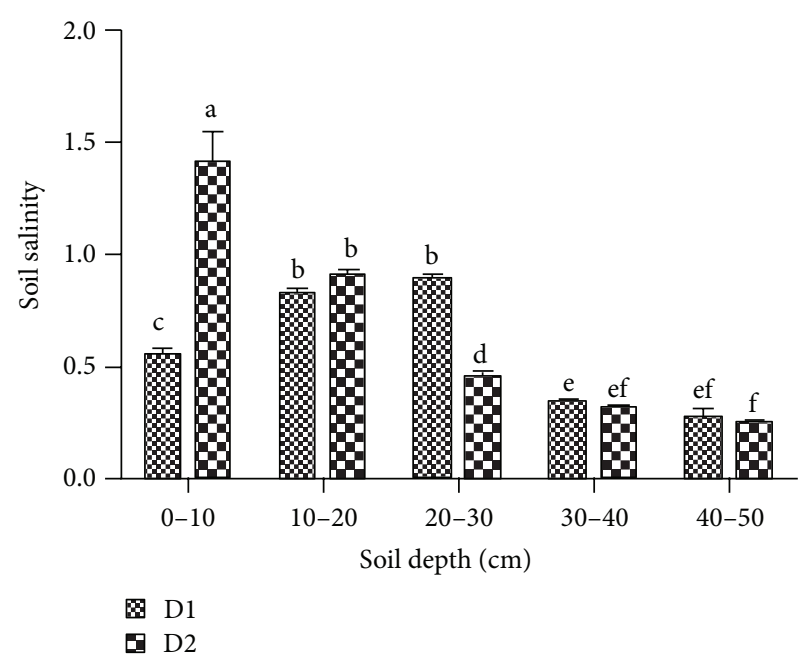

(d)

FIGURE 4: Spatial distribution of soil salinity.

3.2. Data Analysis. Data processing of soil compaction, soil nutrient, and soil microbial biomass $\mathrm{C}$ and $\mathrm{N}$ were performed using Microsoft Excel 2007 and GraphPad Prism 5.0.

One-way ANOVA was used to evaluate the differences among soil salinity of the grazed and fenced floodplain wetlands by SPSS 16.0.

\section{Results}

4.1. Comparison of Soil Compaction in Fenced and Grazed Wetlands. Grazing increased soil compaction (Figure 3), especially in the soil outside the fence. The soil compaction layer found in the A2 association was located at a depth of $5 \mathrm{~cm}$ from the soil surface, and the level of compaction increased with depth. The soil compaction layer found in the B2 association existed at a depth of $7.5 \mathrm{~cm}$ from the soil surface, and the level of soil compaction did not change much with depth. No soil compaction layer was found in the C2 and D2 association. Soil compaction in C2 association increased with depth. The greatest compaction in D2 was located at a depth of $27.5 \mathrm{~cm}$. There were similar trends that soil compaction increased with depth in A1, B1, C1, and D1 association of fenced wetlands. Generally, the soil compaction in wetlands $\mathrm{C}$ and $\mathrm{D}$ was more than in wetlands $\mathrm{A}$ and $\mathrm{B}$.

\subsection{Spatial Distribution of Soil Salinity in Fenced and Grazed} Wetlands. Soil salinity of the top $0-10 \mathrm{~cm}$ in the grazed sites was significantly greater than that of the fenced sites except for the same salinity in sites A1 and 2, while there were no significant differences in soil salinity of most other soil layers in grazed and fenced sites (Figure 4). Generally, with soil depth increasing, soil salinity decreased in fenced and grazed sites. 


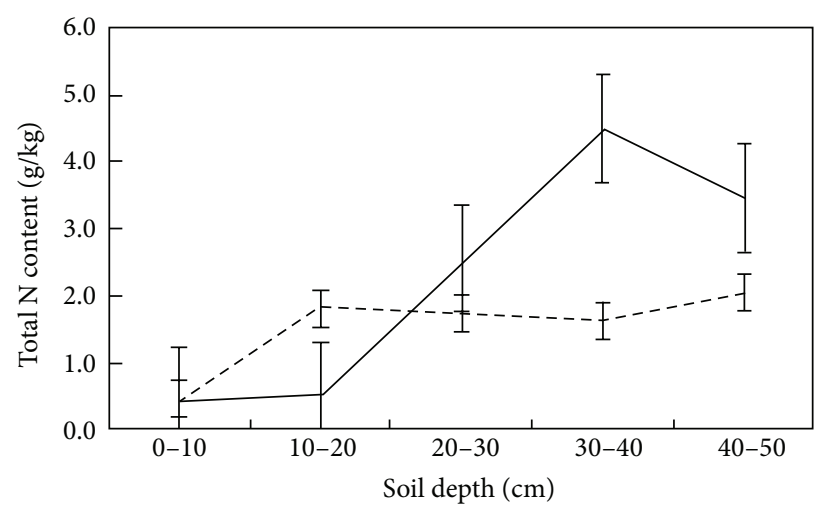

$-\mathrm{A} 1$

(a)

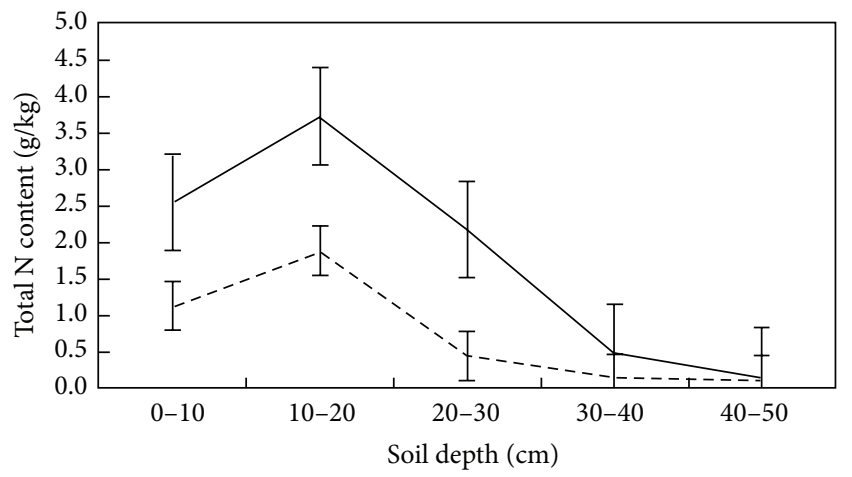

$-\mathrm{C} 1$
$--\mathrm{C} 2$

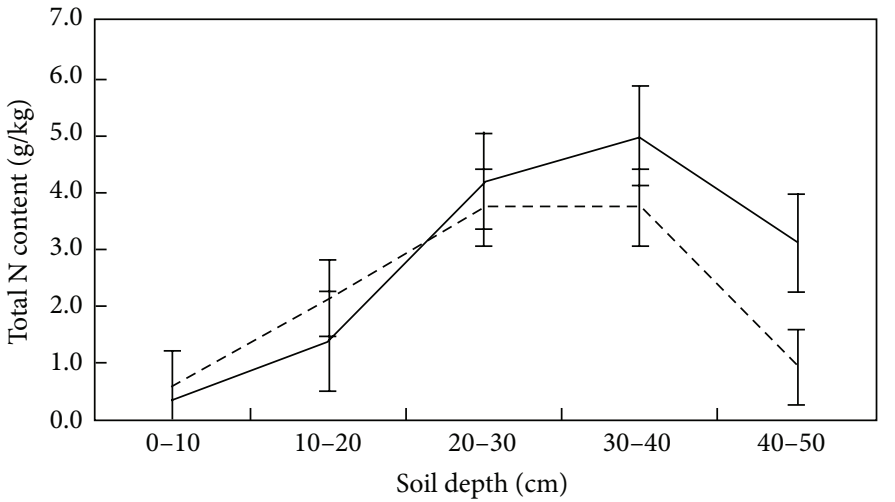

$-\mathrm{B} 1$

$---B 2$

(b)

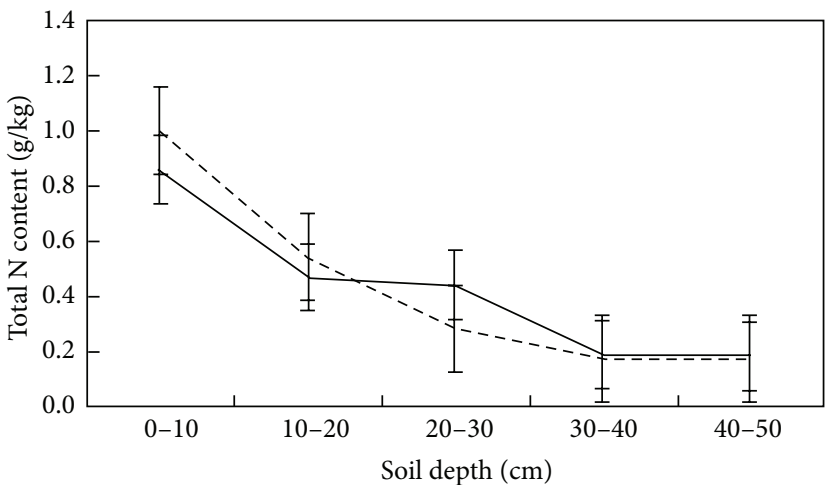

$-\mathrm{D} 1$

(d)

FIGURE 5: Spatial distribution of soil total N content.

4.3. Spatial Distribution of Soil Total N, Soil Total P, and Soil Organic C. The soil total C, N, and P vertical profiles were similar at the fenced and grazed sites except for in the associations of $\mathrm{A} 1$ and $\mathrm{A} 2$, hence grazing did not affect the vertical distribution of soil total $\mathrm{N}$ and $\mathrm{P}$; that is, Maximum soil total C, N, and P content was found at a depth of $20-$ $40 \mathrm{~cm}$ in B1 and B2, at a depth of $10-20 \mathrm{~cm}$ in $\mathrm{C} 1$ and $\mathrm{C} 2$, and at a depth of $0-10 \mathrm{~cm}$ in D1 and D2, whereas Maximum soil total $\mathrm{C}, \mathrm{N}$, and $\mathrm{P}$ content in $\mathrm{A} 1$ was different from in $\mathrm{A} 2$ (Figures 5, 6, and 7).

4.4. Comparison of Soil Microbial Biomass $C$ and N. In the low elevation floodplain wetlands $\mathrm{A}$ and $\mathrm{B}$, soil microbial biomass $\mathrm{C}$ and $\mathrm{N}$ content of the grazed site was greater than that of the fenced site. However, in the transition zone and the high elevation floodplain wetlands $\mathrm{C}$ and $\mathrm{D}$, soil microbial biomass $\mathrm{C}$ and $\mathrm{N}$ content of the grazed site was significantly lower than that of the fenced site (Figure 8). Moreover, contents in soil microbial biomass $\mathrm{C}$ and $\mathrm{N}$ in the high elevation wetlands $\mathrm{C}$ and $\mathrm{D}$ were more than in the low elevation wetlands A and B.

\section{Discussion}

Some studies have reported that grazing and trampling increased soil compaction and soil salinity (e.g., [37, 38]), changed nutrient conditions (e.g., [39-41]), and resulted in a smaller size of individual wetland plant with lower biomass [42-44]. These phenomena also existed in our study results.

Our study further proved that grazing increased soil compaction in the grazed wetland more significantly than in the fenced wetland. Moreover, a compaction layer was formed in the soil surface of sites A2 and B2, while no soil compaction layers were found in the fenced wetlands. This was because undecomposed remains of plant litters accumulated fast in sites $\mathrm{A}$ and $\mathrm{B}$, and trampling of livestock caused these remains to form a compaction layer. The large pores in the wetland soil are the main passage for transporting water, the reduction of which limits the transportation of water and nutrients to the roots $[45,46]$. Generally, trampling reduced soil pore space in the wetland and increased soil compaction $[38,47,48]$. In the grazed sites $\mathrm{A}$ to $\mathrm{D}$, grazing and trampling reduced soil pore space and lowered soil water content in site D more than in 

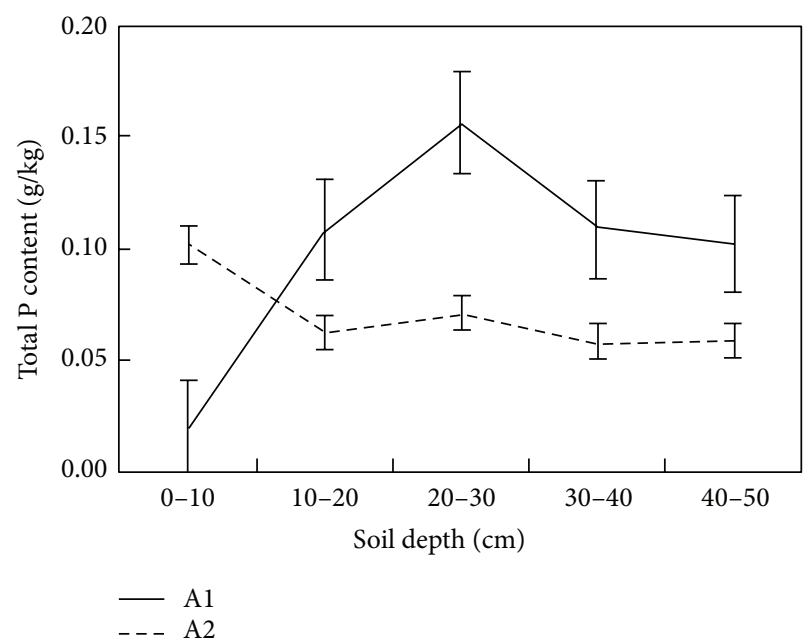

(a)

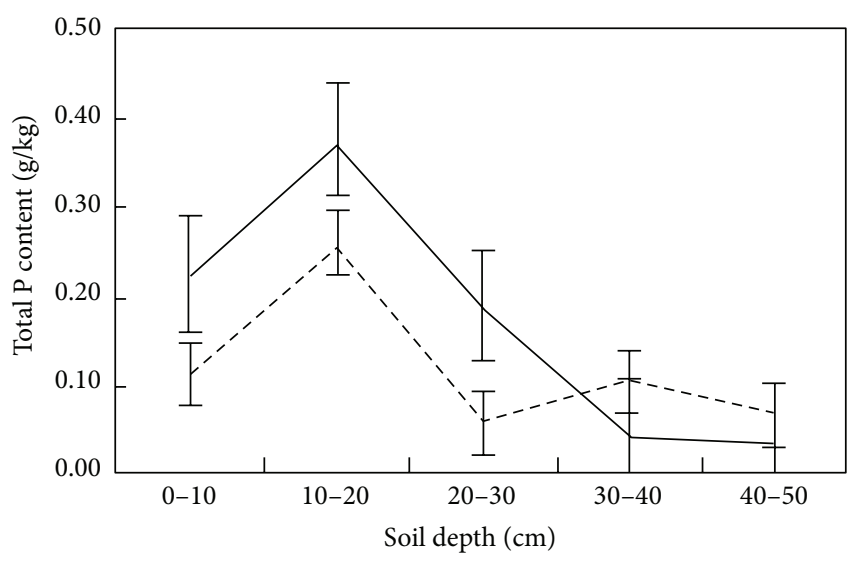

$\mathrm{C} 1$
$---\mathrm{C} 2$

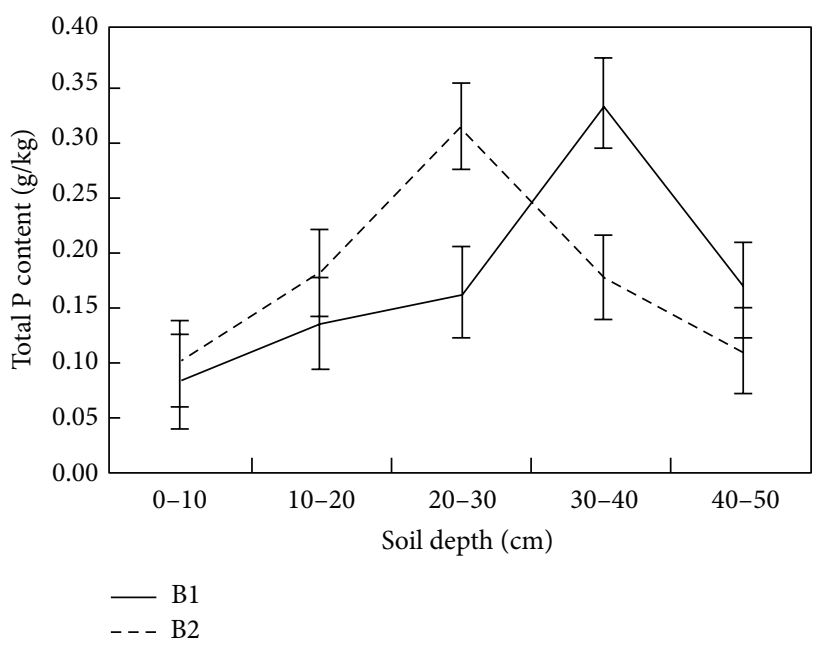

(b)

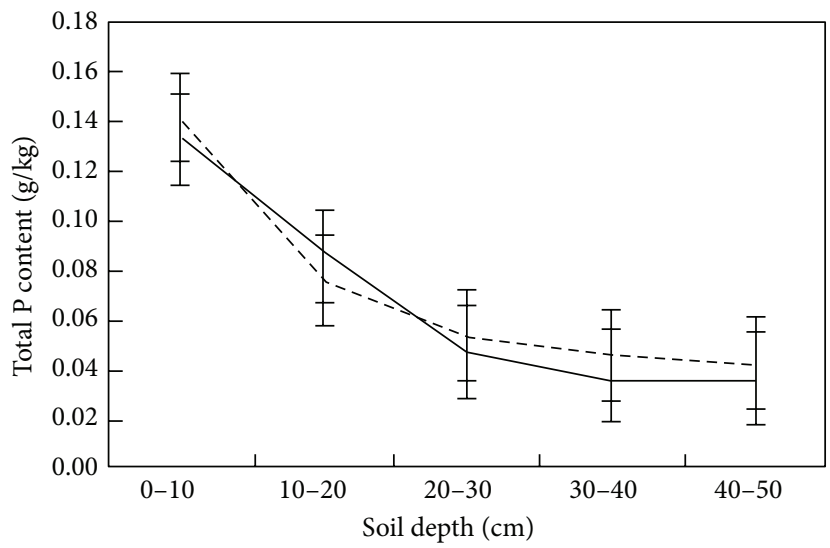

- D1

$---\mathrm{D} 2$

(d)

FIGURE 6: Spatial distribution of soil total P content.

the other sites, which were critical in changing soil physical properties.

Some studies investigated the response of wetland plants to grazing and found that reactions were dependent on hydrological conditions and grazing intensity $[9,49-51]$. Soil water content was thus the main limiting factor for plant productivity [21, 52], and Pietola et al. [53] found that trampling at wetter conditions made surface soil looser and increased the air permeability and saturated hydraulic conductivity, while in deeper soil layers it was contrary. In this study, the floodplain wetlands A to D showed distinctive characteristics in the variety of soil compaction with increasing depth under the influence of grazing, and especially in site D, grazing effects were similar to the findings of Pietola et al. [53]. Grazing could decrease litter accumulation and cause plant functional types change, and heavy grazing would produce higher salinity and less biomass [37], which were obvious in our studies. Our studies further showed that grazing promoted the accumulation of soil salinity of the top $0-10 \mathrm{~cm}$, and $\mathrm{C}, \mathrm{N}$, and $\mathrm{P}$ accumulation increased from shallow soil in sites $\mathrm{D}$ and $\mathrm{C}$ to deep soil on sites $\mathrm{A}$ and $\mathrm{B}$. This was attributed to a decrease in soil water content from sites A and B to site $D$, which was caused by elevation of different sites. Moreover, compositions of plant species varied from sites $\mathrm{A}$ to $\mathrm{D}$, and the abundance of tall and rhizomatous species decreased. The phenomenon of individual plant miniaturization revealed that grazing disturbed plant growth. Hence, depressional wetlands such as sites A and B in riparian floodplain benefited from organic $\mathrm{C}$ and nutrient accumulation and increased plant species richness.

The shift in elevation of riparian floodplain wetlands added to the spatial heterogeneity of wetland soil, which was also shown in the variations of soil microbial biomass $\mathrm{C}$ and $\mathrm{N}$ in this study. Grazing intensity increased soil microbial biomass $\mathrm{C}$ and $\mathrm{N}$ clearly $[54,55]$ and stagnant flood conditions also decreased microbial biomass [56], which explained that higher soil microbial biomass $\mathrm{C}$ and $\mathrm{N}$ existed in the higher elevation wetlands $\mathrm{C}$ and $\mathrm{D}$ for their higher 

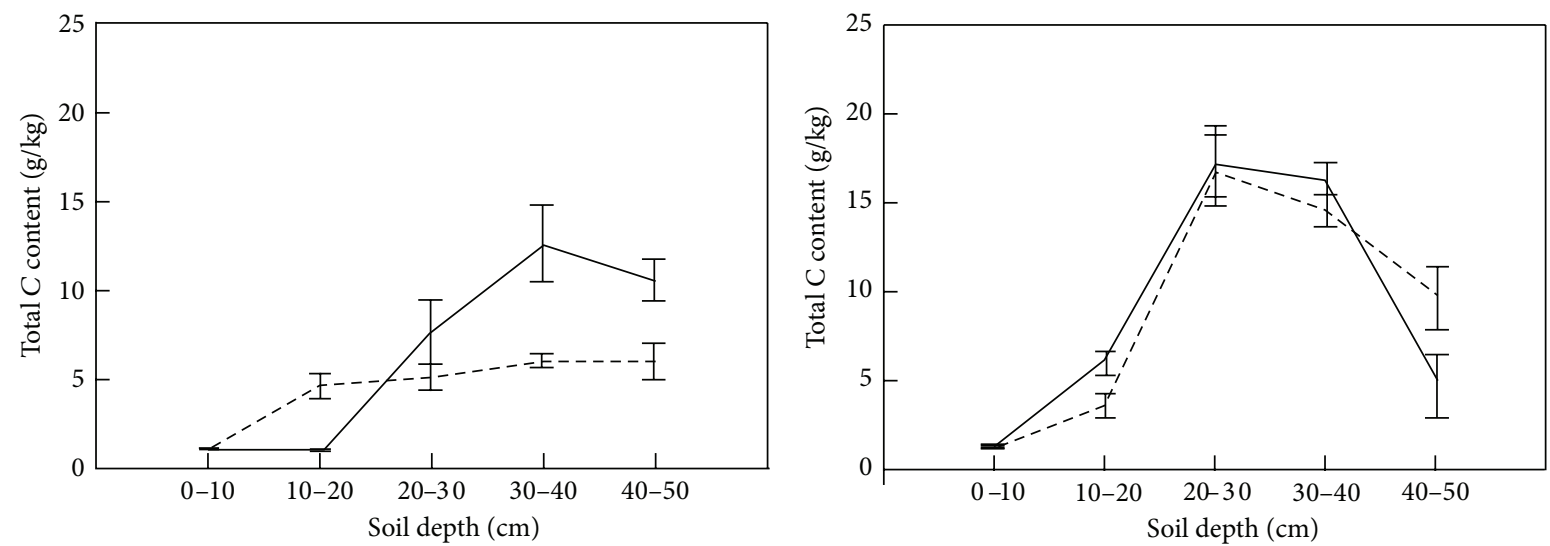

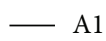

$--\mathrm{A} 2$

(a)

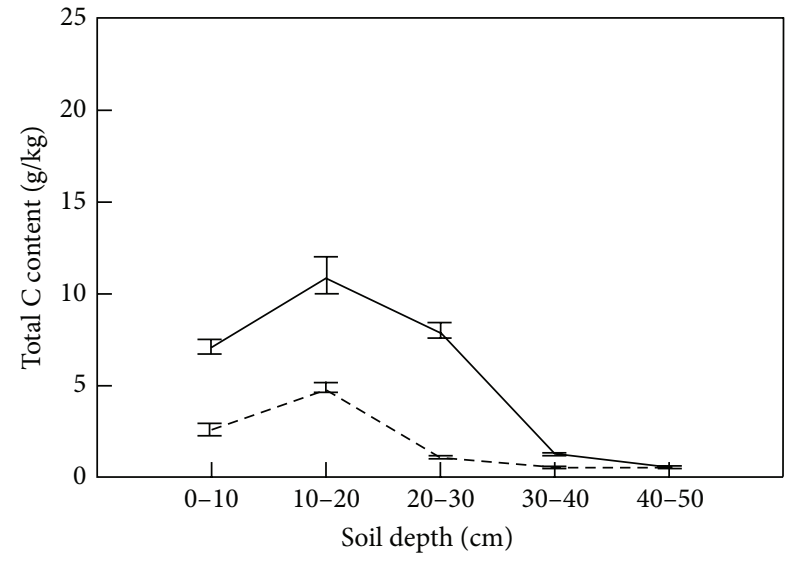

$-\mathrm{C} 1$
$---\mathrm{C} 2$
$-\mathrm{B} 1$

$---B 2$

(b)

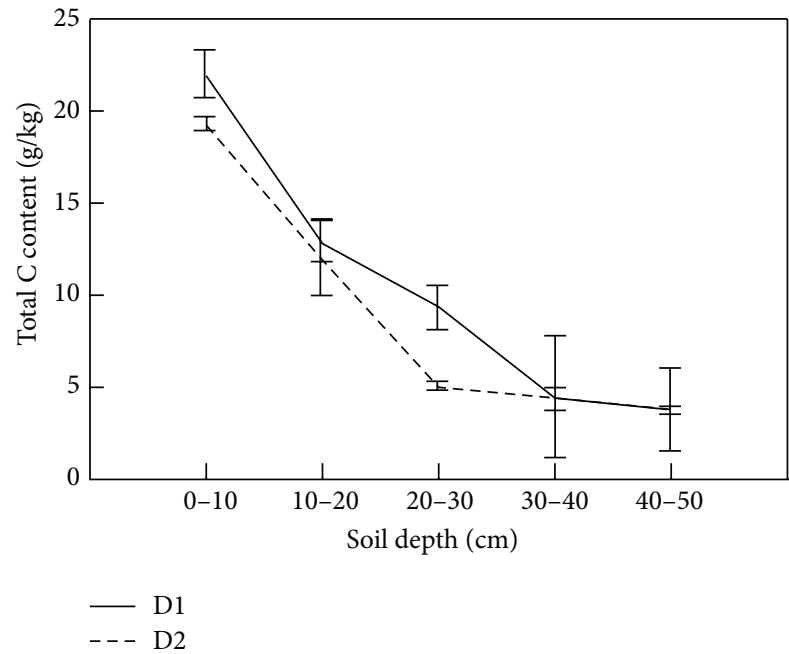

(d)

FIgURE 7: Spatial distribution of soil total C content.

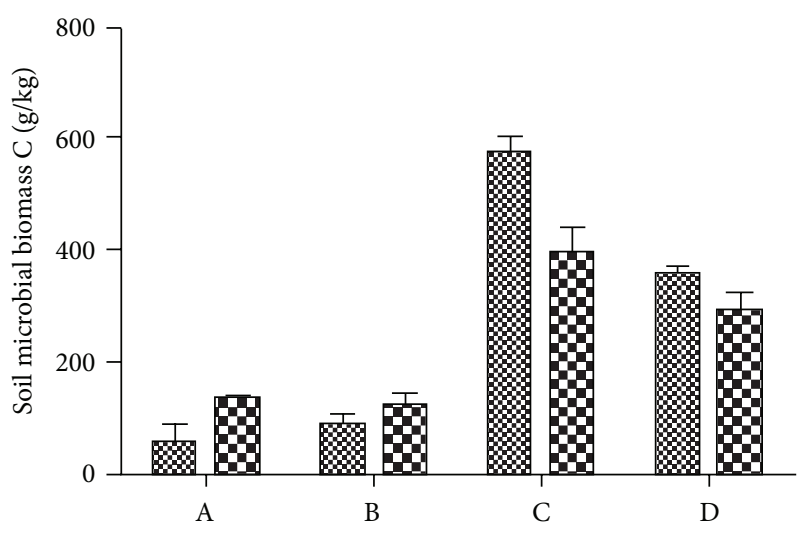

8. Fenced sites 回 Grazed sites

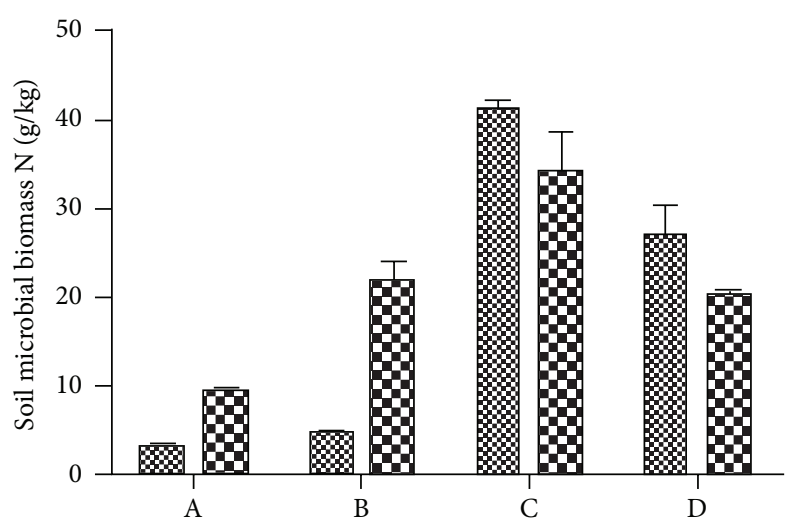

B Fenced sites Grazed sites

(a)

FIgURE 8: Spatial distribution of soil microbial biomass C and N. 
grazing intensity and fewer inundation. The decrease in the number of soil pores limited the growing space for microbes and decreased microbial respiration [57]. The reduction in microbes broke efficient belowground cycles and thus lowered belowground productivity, that is, less root biomass $[58,59]$. This phenomenon was obvious in sites $C$ and $D$. If extensive grazing still continued, plant productivity of the riparian wetland would further decrease and eventually result in extreme ecosystem degradation $[19,29]$. Wetland degradation caused less water infiltration, greater surface runoff, and more soil nutrient loss [60-63]. Therefore, grazing also lowered soil total $\mathrm{N}$ and total $\mathrm{P}$ content in the wetland [37, 64].

All of these changes of the wetland soil resulting from grazing were consistent with the responses of typical degraded steppe to grazing, including lower soil nutrient contents, more compact soil with a compaction layer at the soil surface, and salinized soil [65-69]. Therefore, we should realize the importance of conserving wetland and grassland ecosystems in Xilin River riparian floodplain wetland and strengthen the management of grazing to restore ecosystem health of riparian floodplain wetland.

\section{Conclusion}

Comparison of the soil in the fenced and grazed riparian floodplain wetland in the steppe region of the Inner Mongolian Plateau showed that grazing and trampling from livestock resulted in a more compact soil with a surface compaction layer and less TOC, total $\mathrm{N}$, and total $\mathrm{P}$ concentration. Overgrazing produced more exposed soil surfaces, greater soil surface salinity with a tendency towards salinization, and degradation of wetland vegetation. However, variable elevations of riparian floodplain wetlands formed greater spatial heterogeneity in wetland soil and vegetation composition, and thus different topographical characteristics displayed in the influence of grazing on riparian floodplain wetland. Additionally, wetland plant communities at a higher elevation location in riparian floodplain wetland endured more grazing pressures.

\section{Conflict of Interests}

The authors declare that there is no conflict of interests regarding the publication of this paper.

\section{Authors' Contribution}

Lixin Wang and Huamin Liu contributed to the work in the paper equally.

\section{Acknowledgments}

This study was supported by the National Key Basic Research Program of China (no. 2014CB138802), the National Key Technology R\&D Program of China (nos. 2011BAC02B03 and 2013BAC09B03), and the National Natural Science Funds of China (nos. 31060076 and 41261009).

\section{References}

[1] P. Dugan, Wetlands in Danger, Mitchell Beazley, London, UK, 1992.

[2] K. D. Schuyt, "Economic consequences of wetland degradation for local populations in Africa," Ecological Economics, vol. 53, no. 2, pp. 177-190, 2005.

[3] J. B. Zedler, "Progress in wetland restoration ecology," Trends in Ecology and Evolution, vol. 15, no. 10, pp. 402-407, 2000.

[4] J. Bai, B. Cui, H. Cao, A. Li, and B. Zhang, "Wetland degradation and ecological restoration," The Scientific World Journal, vol. 2013, Article ID 523632, 2 pages, 2013.

[5] P. Banaszuk and A. Kamocki, "Effects of climatic fluctuations and land-use changes on the hydrology of temperate fluviogenous mire," Ecological Engineering, vol. 32, no. 2, pp. 133$146,2008$.

[6] K. L. Erwin, "Wetlands and global climate change: the role of wetland restoration in a changing world," Wetlands Ecology and Management, vol. 17, no. 1, pp. 71-84, 2009.

[7] J. Álvarez-Rogel, F. J. Jiménez-Cárceles, M. J. Roca, and R. Ortiz, "Changes in soils and vegetation in a Mediterranean coastal salt marsh impacted by human activities," Estuarine, Coastal and Shelf Science, vol. 73, no. 3-4, pp. 510-526, 2007.

[8] Z. Luan and D. Zhou, "Impacts of intensified agriculture developments on marsh wetlands," The Scientific World Journal, vol. 2013, Article ID 409439, 10 pages, 2013.

[9] W. M. Jones, L. H. Fraser, and P. J. Curtis, "Plant community functional shifts in response to livestock grazing in intermountain depressional wetlands in British Columbia, Canada," Biological Conservation, vol. 144, no. 1, pp. 511-517, 2011.

[10] P. Laffaille, J.-C. Lefeuvre, and E. Feunteun, "Impact of sheep grazing on juvenile sea bass, Dicentrarchus labrax L., in tidal salt marshes," Biological Conservation, vol. 96, no. 3, pp. 271-277, 2000.

[11] Y. S. Olsen, A. Dausse, A. Garbutt, H. Ford, D. N. Thomas, and D. L. Jones, "Cattle grazing drives nitrogen and carbon cycling in a temperate salt marsh," Soil Biology and Biochemistry, vol. 43, no. 3, pp. 531-541, 2011.

[12] M. A. Reid, R. Ogden, and M. C. Thoms, "The influence of flood frequency, geomorphic setting and grazing on plant communities and plant biomass on a large dryland floodplain," Journal of Arid Environments, vol. 75, no. 9, pp. 815-826, 2011.

[13] R. J. Reimold, R. A. Linthurst, and P. L. Wolf, "Effects of grazing on a salt marsh," Biological Conservation, vol. 8, no. 2, pp. 105125, 1975.

[14] N. Rossignol, A. Bonis, and J.-B. Bouzillé, "Consequence of grazing pattern and vegetation structure on the spatial variations of net $\mathrm{N}$ mineralisation in a wet grassland," Applied Soil Ecology, vol. 31, no. 1-2, pp. 62-72, 2006.

[15] Z.-Y. Wang, Y.-Z. Xin, D.-M. Gao, F.-M. Li, J. Morgan, and B.S. Xing, "Microbial community characteristics in a degraded wetland of the Yellow River Delta," Pedosphere, vol. 20, no. 4, pp. 466-478, 2010.

[16] D. Moreno-Mateos, M. E. Power, F. A. Comín, and R. Yockteng, "Structural and functional loss in restored wetland ecosystems," PLoS Biology, vol. 10, no. 1, Article ID e1001247, 2012.

[17] I. Douterelo, R. Goulder, and M. Lillie, "Soil microbial community response to land-management and depth, related to the degradation of organic matter in English wetlands: implications for the in situ preservation of archaeological remains," Applied Soil Ecology, vol. 44, no. 3, pp. 219-227, 2010. 
[18] H. M. Yao, J. Bai, and Z. Zhang, "Variations of soil organic matter and nutrients in degenerated wetland in response to ecological restoration in shuangtaizi erstuary, Northeast China," Advanced Materials Research, vol. 664, pp. 48-54, 2013.

[19] W. J. Li, S. H. Ali, and Q. Zhang, "Property rights and grassland degradation: a study of the Xilingol Pasture, Inner Mongolia, China," Journal of Environmental Management, vol. 85, no. 2, pp. 461-470, 2007.

[20] D. M. Williams, "Grassland enclosures: catalyst of land degradation in Inner Mongolia," Human Organization, vol. 55, no. 3, pp. 307-313, 1996.

[21] Y. Z. Gao, M. Giese, S. Lin, B. Sattelmacher, Y. Zhao, and H. Brueck, "Belowground net primary productivity and biomass allocation of a grassland in Inner Mongolia is affected by grazing intensity," Plant and Soil, vol. 307, no. 1-2, pp. 41-50, 2008.

[22] Y. Bai, L. Li, Q. Wang, L. Zhang, Y. Zhang, and Z. Chen, "Changes in plant species diversity and productivity along gradients of precipitation and elevation in the Xilin River Basin, Inner Mongolia," Acta Phytoecologica Sinica, vol. 24, no. 6, pp. 667-673, 2000.

[23] J. W. Li, L. X. Wang, W. Wang, C. Z. Liang, and H. M. Liu, "Characterization of degradation of wetland plant communities on floodplain in typical steppe region of Inner Mongolia Plateau, China," Chinese Journal of Plant Ecology, vol. 36, no. 1, pp. 10$18,2012$.

[24] H. Olff and M. E. Ritchie, "Effects of herbivores on grassland plant diversity," Trends in Ecology and Evolution, vol. 13, no. 7, pp. 261-265, 1998.

[25] P. Adler, D. Raff, and W. Lauenroth, "The effect of grazing on the spatial heterogeneity of vegetation," Oecologia, vol. 128, no. 4, pp. 465-479, 2001.

[26] H. Olff and M. E. Ritchie, "Effects of herbivores on grassland plant diversity," Trends in Ecology and Evolution, vol. 13, no. 7, pp. 261-265, 1998.

[27] A. Altesor, M. Oesterheld, E. Leoni, F. Lezama, and C. Rodríguez, "Effect of grazing on community structure and productivity of a Uruguayan grassland," Plant Ecology, vol. 179, no. 1, pp. 83-91, 2005.

[28] B. Peco, I. de Pablos, J. Traba, and C. Levassor, "The effect of grazing abandonment on species composition and functional traits: the case of dehesa grasslands," Basic and Applied Ecology, vol. 6, no. 2, pp. 175-183, 2005.

[29] P. Schönbach, H. Wan, M. Gierus et al., "Grassland responses to grazing: effects of grazing intensity and management system in an Inner Mongolian steppe ecosystem," Plant and Soil, vol. 340, no. 1, pp. 103-115, 2011.

[30] A. Zemmrich, M. Manthey, S. Zerbe, and D. Oyunchimeg, "Driving environmental factors and the role of grazing in grassland communities: a comparative study along an altitudinal gradient in Western Mongolia," Journal of Arid Environments, vol. 74, no. 10, pp. 1271-1280, 2010.

[31] Z. Luan, Z. Wang, D. Yan, G. Liu, and Y. Xu, "The ecological response of carex lasiocarpa community in the riparian wetlands to the environmental gradient of water depth in sanjiang plain, Northeast China," The Scientific World Journal, vol. 2013, Article ID 402067, 7 pages, 2013.

[32] M. A. Tabatabai and W. A. Dick, "Simultaneous determination of nitrate, chloride, sulfate, and phosphate in natural waters by ion chromatography," Journal of Environmental Quality, vol. 12, no. 2, pp. 209-213, 1983.

[33] A. Braun, M. Wolter, F. Zadrazil, G. Flachowsky, C. Mba, and L. V. Griensven, "Bioconversion of wheat straw by Lentinus tuber-regium and its potential utilization as food, medicine and animal feed," in Science and Cultivation of Edible Fungi, A. Van Griensven and A. A. Balkema, Eds., pp. 549-558, 2000.

[34] E. D. Vance, P. C. Brookes, and D. S. Jenkinson, "An extraction method for measuring soil microbial biomass C," Soil Biology and Biochemistry, vol. 19, no. 6, pp. 703-707, 1987.

[35] Y. Li, T. Wang, J. Li, and Y. Ao, "Effect of phosphorus on celery growth and nutrient uptake under different calcium and magnesium levels in substrate culture," Horticultural Science, vol. 37, no. 3, pp. 99-108, 2010.

[36] K. E. Segarra, Source or Sink? Analysis of Narragansett Bay's Carbon Cycle, Brown University, 2002.

[37] L. M. Teuber, N. Hoelzel, and L. H. Fraser, "Livestock grazing in intermountain depressional wetlands-effects on plant strategies, soil characteristics and biomass," Agriculture Ecosystems \& Environment, vol. 175, pp. 21-28, 2013.

[38] A. J. Belsky and D. M. Blumenthal, "Effects of livestock grazing on stand dynamics and soils in upland forests of the Interior West," Conservation Biology, vol. 11, no. 2, pp. 315-327, 1997.

[39] R. A. Golluscio, A. T. Austin, G. C. García Martínez, M. Gonzalez-Polo, O. E. Sala, and R. B. Jackson, "Sheep grazing decreases organic carbon and nitrogen pools in the patagonian steppe: combination of direct and indirect effects," Ecosystems, vol. 12, no. 4, pp. 686-697, 2009.

[40] E. S. Bakker, H. Olff, M. Boekhoff, J. M. Gleichman, and F. Berendse, "Impact of herbivores on nitrogen cycling: contrasting effects of small and large species," Oecologia, vol. 138, no. 1, pp. 91-101, 2004.

[41] J. D. Reeder and G. E. Schuman, "Influence of livestock grazing on $\mathrm{C}$ sequestration in semi-arid mixed-grass and short-grass rangelands," Environmental Pollution, vol. 116, no. 3, pp. 457$463,2002$.

[42] J. Zimmermann, S. I. Higgins, V. Grimm, J. Hoffmann, and A. Linstädter, "Grass mortality in semi-arid savanna: the role of fire, competition and self-shading," Perspectives in Plant Ecology, Evolution and Systematics, vol. 12, no. 1, pp. 1-8, 2010.

[43] G.-L. Wu, G.-Z. Du, Z.-H. Liu, and S. Thirgood, "Effect of fencing and grazing on a Kobresia-dominated meadow in the Qinghai-Tibetan Plateau," Plant and Soil, vol. 319, no. 1-2, pp. 115-126, 2009.

[44] W. Wang, C. Z. Liang, Z. L. Liu, and D. Y. Hao, "Mechanism of degradation succession in Leymus chinensis + Stipa grandis steppe community," Acta Phytoecologica Sinica, vol. 24, no. 4, pp. 468-472, 2000.

[45] J. J. Drewry, J. A. H. Lowe, and R. J. Paton, "Effect of sheep stocking intensity on soil physical properties and dry matter production on a Pallic Soil in Southland," New Zealand Journal of Agricultural Research, vol. 42, no. 4, pp. 493-499, 1999.

[46] J. M. Warren, J. R. Brooks, M. I. Dragila, and F. C. Meinzer, "In situ separation of root hydraulic redistribution of soil water from liquid and vapor transport," Oecologia, vol. 166, no. 4, pp. 899-911, 2011.

[47] D. H. McNabb, A. D. Startsev, and H. Nguyen, "Soil wetness and traffic level effects on bulk density and air-filled porosity of compacted boreal forest soils," Soil Science Society of America Journal, vol. 65, no. 4, pp. 1238-1247, 2001.

[48] M. A. Wheeler, M. J. Trlica, G. W. Frasier, and J. D. Reeder, "Seasonal grazing affects soil physical properties of a montane riparian community," Journal of Range Management, vol. 55, no. 1, pp. 49-56, 2002. 
[49] J. E. Austin, J. R. Keough, and W. H. Pyle, "Effects of habitat management treatments on plant community composition and biomass in a Montane wetland," Wetlands Ecology and Management, vol. 27, no. 3, pp. 570-587, 2007.

[50] R. W. Lucas, T. T. Baker, M. K. Wood, C. D. Allison, and D. M. Vanleeuwen, "Riparian vegetation response to different intensities and seasons of grazing," Journal of Range Management, vol. 57, no. 5, pp. 466-474, 2004.

[51] T. T. Schulz and W. C. Leininger, "Differences in riparian vegetation structure between grazed areas and exclosures," Journal of Range Management, vol. 43, no. 4, pp. 295-299, 1990.

[52] W. Webb, S. Szarek, W. Lauenroth, R. Kinerson, and M. Smith, "Primary productivity and water use in native forest, grassland, and desert ecosystems," Ecology, vol. 59, no. 6, pp. 1239-1247, 1978.

[53] L. Pietola, R. Horn, and M. Yli-Halla, "Effects of trampling by cattle on the hydraulic and mechanical properties of soil," Soil and Tillage Research, vol. 82, no. 1, pp. 99-108, 2005.

[54] K.-H. Wang, R. McSorley, P. Bohlen, and S. M. Gathumbi, "Cattle grazing increases microbial biomass and alters soil nematode communities in subtropical pastures," Soil Biology and Biochemistry, vol. 38, no. 7, pp. 1956-1965, 2006.

[55] R. D. Bardgett, D. K. Leemans, R. Cook, and P. J. Hobbs, "Seasonality in the soil biota of grazed and ungrazed hill grasslands," Soil Biology and Biochemistry, vol. 29, no. 8, pp. 1285-1294, 1997.

[56] I. M. Unger, A. C. Kennedy, and R.-M. Muzika, "Flooding effects on soil microbial communities," Applied Soil Ecology, vol. 42, no. 1, pp. 1-8, 2009.

[57] P. Jouquet, G. Huchet, N. Bottinelli, T. D. Thu, and T. T. Duc, "Does the influence of earthworms on water infiltration, nitrogen leaching and soil respiration depend on the initial soil bulk density? A mesocosm experiment with the endogeic species Metaphire posthuma," Biology and Fertility of Soils, vol. 48, no. 5, pp. 561-567, 2012.

[58] M. Luke McCormack and C. W. Fernandez, "Measuring and modeling roots, the rhizosphere, and microbial processes belowground," The New phytologist, vol. 192, no. 3, pp. 573-575, 2011.

[59] P. M. Haygarth, R. D. Bardgett, and L. M. Condron, "Nitrogen and phosphorus cycles and their management," in Gregory Soil Conditions and Plant Growth, P. H. Gregory and S. Nortcliff, Eds., pp. 132-159, John Wiley \& Sons, 2012.

[60] C. Huang, J. Bai, H. Shao et al., "Changes in soil properties before and after wetland degradation in the Yellow River Delta, China," CLEAN-Soil, Air, Water, vol. 40, no. 10, pp. 1125-1130, 2012.

[61] K. Ballantine, R. Schneider, P. Groffman, and J. Lehmann, "Soil properties and vegetative development in four restored freshwater depressional wetlands," Soil Science Society of America Journal, vol. 76, no. 4, pp. 1482-1495, 2012.

[62] L. Huo, Z. Chen, Y. Zou, X. Lu, J. Guo, and X. Tang, "Effect of Zoige alpine wetland degradation on the density and fractions of soil organic carbon," Ecological Engineering, vol. 51, pp. 287295, 2013.

[63] J. Bai, H. Ouyang, R. Xiao et al., "Spatial variability of soil carbon, nitrogen, and phosphorus content and storage in an alpine wetland in the Qinghai-Tibet Plateau, China," Australian Journal of Soil Research, vol. 48, no. 8, pp. 730-736, 2010.

[64] J. Reader and C. Craft, "Comparison of wetland structure and function on grazed and ungrazed salt marshes," Journal of the Elisha Mitchell Scientific Society, vol. 115, no. 4, pp. 236-249, 1999.

[65] R. S. Lavado, J. O. Sierra, and P. N. Hashimoto, "Impact of grazing on soil nutrients in a Pampean grassland," Journal of Range Management, vol. 49, no. 5, pp. 452-457, 1996.

[66] S. Yong-Zhong, L. Yu-Lin, C. Jian-Yuan, and Z. Wen-Zhi, "Influences of continuous grazing and livestock exclusion on soil properties in a degraded sandy grassland, Inner Mongolia, northern China," Catena, vol. 59, no. 3, pp. 267-278, 2005.

[67] A. B. Frank, D. L. Tanaka, L. Hofmann, and R. F. Follett, "Soil carbon and nitrogen of Northern Great Plains grasslands as influenced by long-term grazing," Journal of Range Management, vol. 48, no. 5, pp. 470-474, 1995.

[68] G. Pineiro, J. M. Paruelo, M. Oesterheld, and E. G. Jobbágy, "Pathways of grazing effects on soil organic carbon and nitrogen," Rangeland Ecology and Management, vol. 63, no. 1, pp. 109$119,2010$.

[69] X. M. Shi, X. G. Li, C. T. Li, Y. Zhao, Z. H. Shang, and Q. $\mathrm{Ma}$, "Grazing exclusion decreases soil organic $\mathrm{C}$ storage at an alpine grassland of the Qinghai-Tibetan Plateau," Ecological Engineering, vol. 57, pp. 183-187, 2013. 

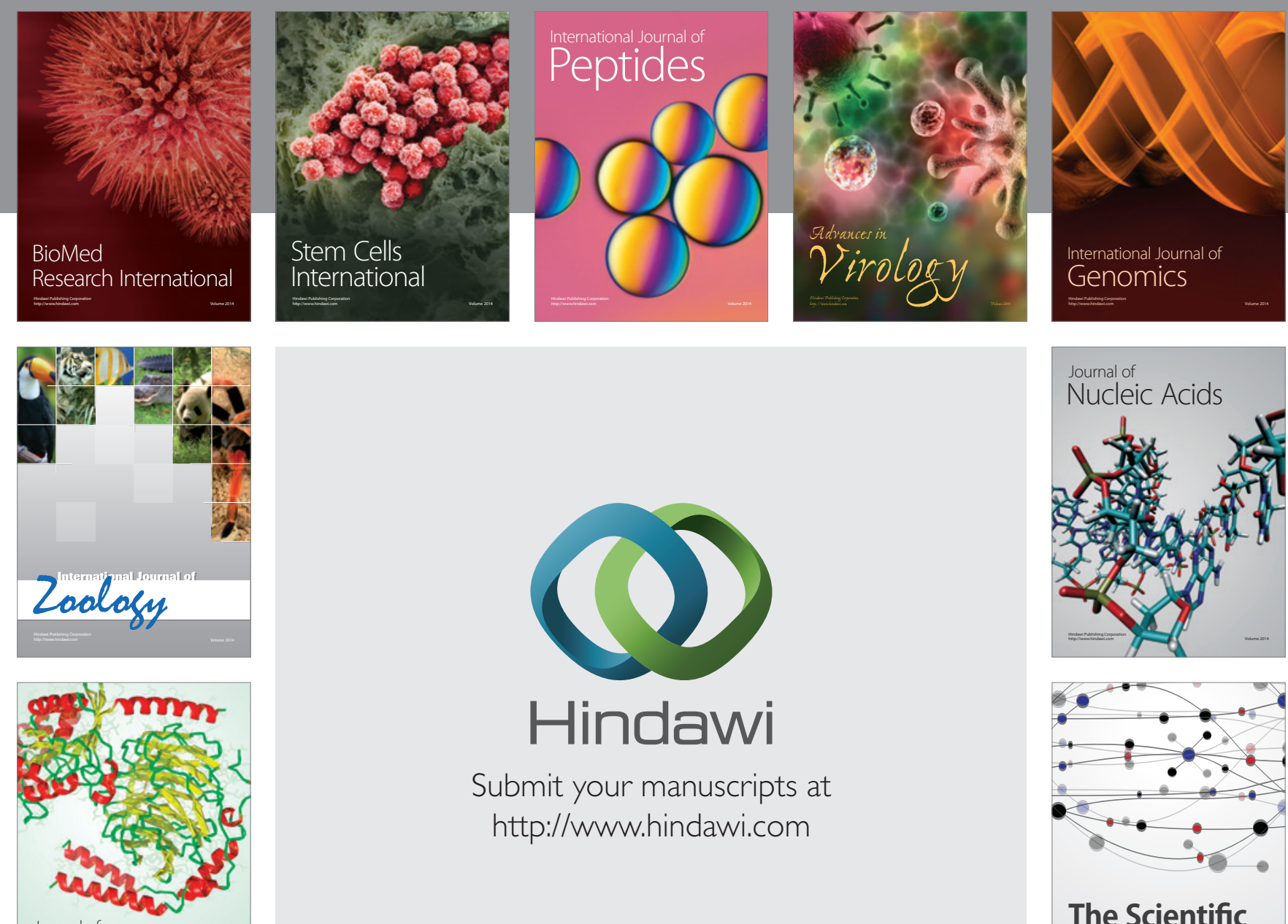

Submit your manuscripts at

http://www.hindawi.com

Journal of
Signal Transduction
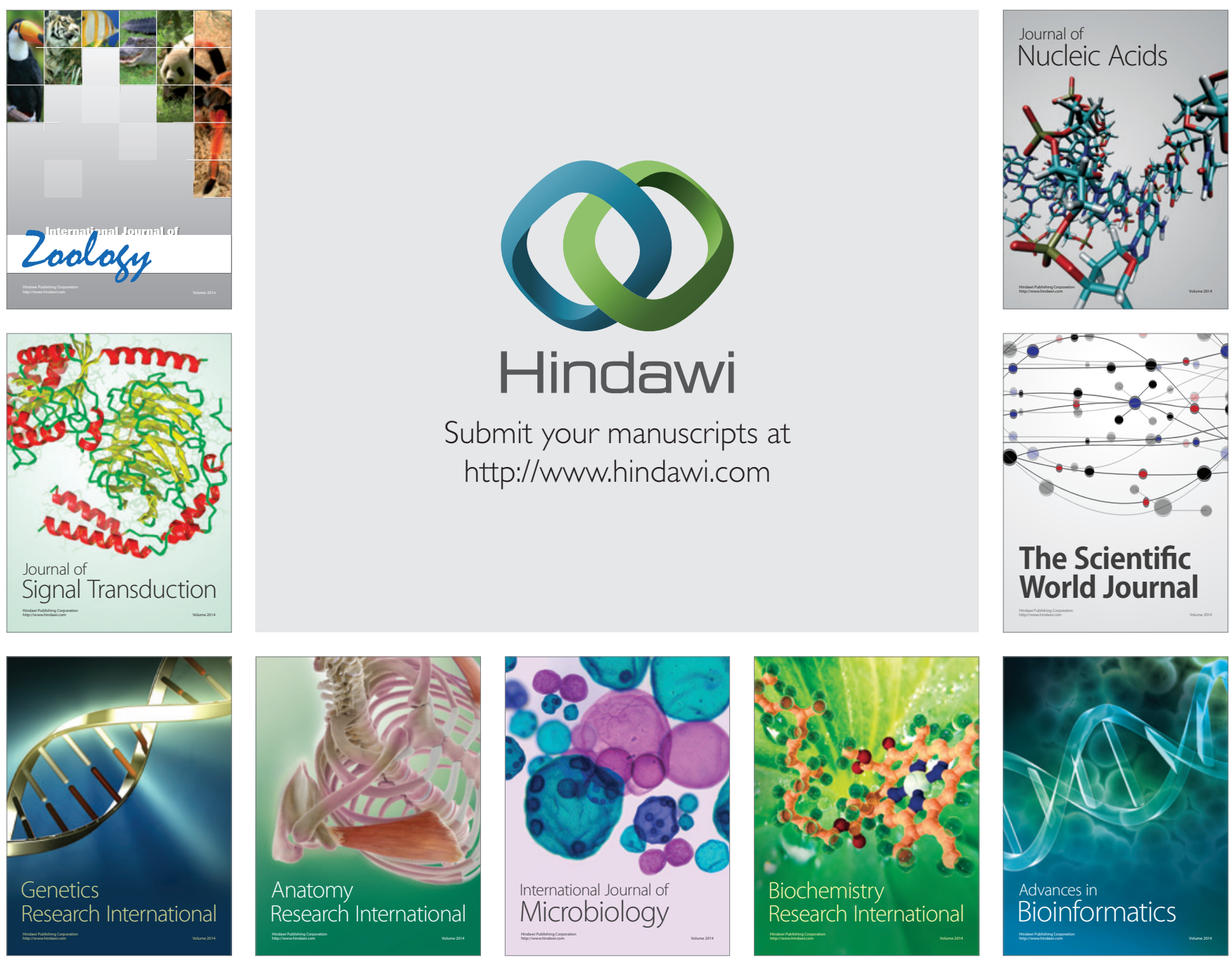

The Scientific World Journal
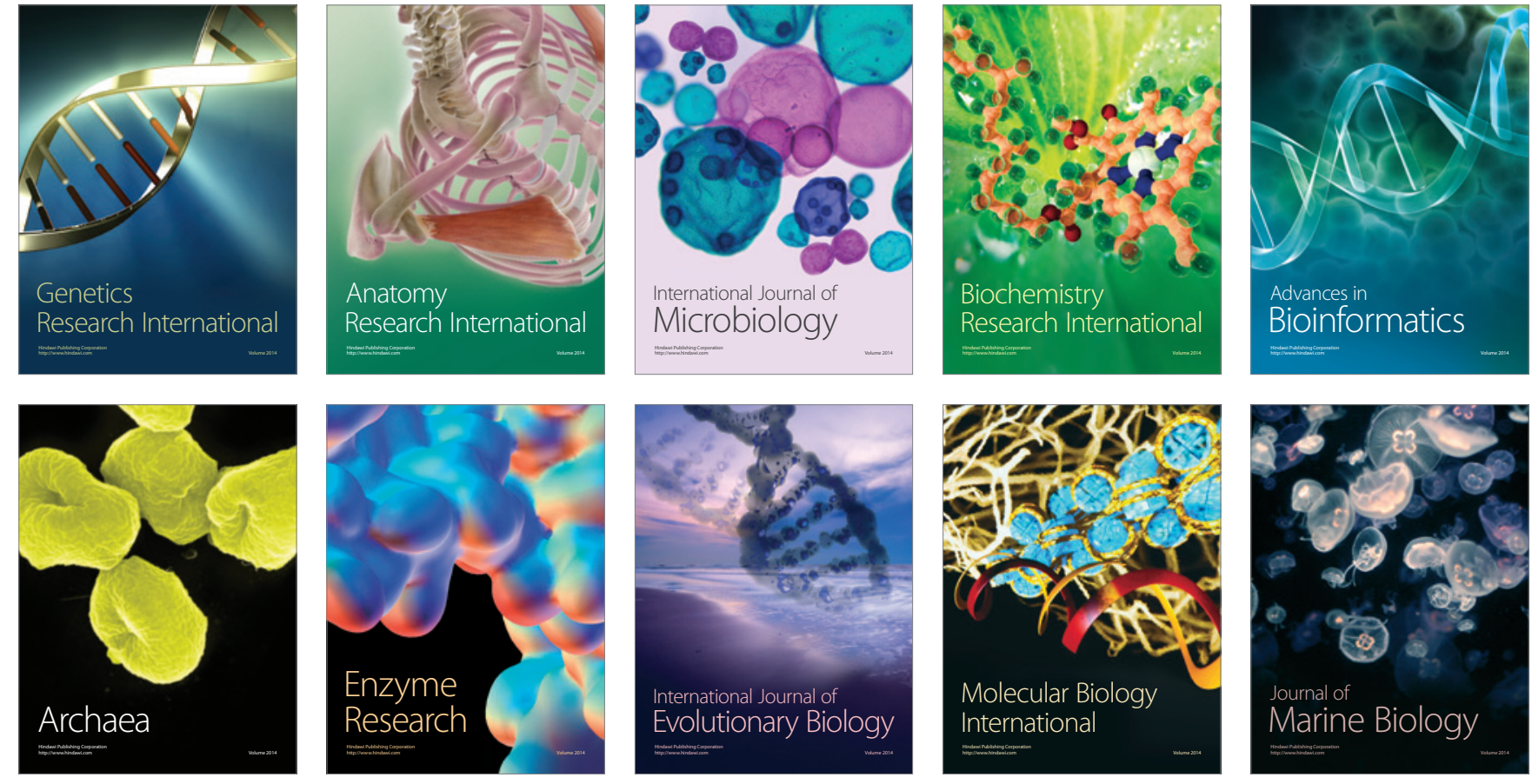